\title{
The influence of selected factors on the degree of illness acceptance and on the level of satisfaction with life in patients hospitalised in cardiology departments
}

\section{Wpływ wybranych czynników na stopień akceptacji choroby i poziom satysfakcji $z$ życia u pacjentów leczonych na oddziałach kardiologicznych}

\author{
Katarzyna I. Białek, Marcin Sadowski
}

Institute of Medical Sciences, Faculty of Medicine and Health Sciences, Jan Kochanowski University, Collegium Medicum, Kielce, Poland Head of the Institute: Beata Kręcisz MD, PhD, Prof. JKU

Key words: acceptance of illness, satisfaction with life, cardiovascular disease, hospitalisation.

Słowa kluczowe: akceptacja choroby, satysfakcja z życia, choroby serca, hospitalizacja.

\begin{abstract}
Introduction: Cardiovascular diseases are a major cause of health and social problems worldwide. Poor acceptance of illness is considered a prognostic factor for worse satisfaction with life.

Aim of the research: To determine the influence of selected factors on the degree of disease acceptance and the level of life satisfaction in patients treated in cardiac wards, as well as to assess whether the level of disease acceptance affects the feeling of life satisfaction and vice versa.

Material and methods: The study was conducted in a group of 104 patients hospitalised in cardiac units. To evaluate the acceptance of illness and satisfaction with life the standardised Acceptance of Illness Scale (AIS) and Satisfaction with Life Scale (SWLS) were used.

Results: The mean value of overall illness acceptance was $22.88 \pm 2.86$, which indicated an average level of illness acceptance among the patients. Average satisfaction with life was reported by as many as $50.96 \%(n=53)$ of the patients. The level of acceptance of illness depended on age $(p<0.001)$, marital status $(p=0.002)$, living with family $(p=0.001)$, educational background $(p=0.021)$, and frequency of hospital treatment $(p=0.04)$. The variables marital status $(p<0.001)$ and living with family $(p<0.001)$ had a statistically significant effect on the degree of satisfaction with life. The acceptance of illness was significantly positively correlated with SWLS $(p<0.001)$. Patients declared an average degree of acceptance of illness and satisfaction with life.
\end{abstract}

Conclusions: The relationship between acceptance of illness and satisfaction with life should be further investigated.

\section{Streszczenie}

Wprowadzenie: Choroby sercowo-naczyniowe są główną przyczyną problemów zdrowotnych i społecznych na świecie. Niska akceptacja choroby jest uznawana za czynnik prognostyczny gorszej satysfakcji z życia.

Cel pracy: Określenie wpływu wybranych czynników na stopień akceptacji choroby i poziom zadowolenia z życia pacjentów leczonych na oddziałach kardiologicznych, a także ocena, czy poziom akceptacji choroby wpływa na poczucie zadowolenia z życia i odwrotnie.

Materiał i metody: Badanie przeprowadzono u 104 pacjentów hospitalizowanych na oddziałach kardiologicznych. Do oceny akceptacji choroby i zadowolenia z życia zastosowano Skalę akceptacji choroby (AIS) i Skalę satysfakcji z życia (SWLS). Wyniki: Średnia wartość akceptacji choroby wynosiła $22,88 \pm 2,86$ i wskazywała na średni poziom akceptacji choroby przez pacjentów. Średnie zadowolenie z życia zgłosiło aż 50,96\% $(n=53)$ pacjentów. Poziom akceptacji choroby zależał od wieku $(p<0,001)$, stanu cywilnego $(p=0,002)$, zamieszkania z rodziną $(p=0,001)$, wykształcenia $(p=0,021)$ i częstości leczenia szpitalnego $(p=0,04)$. Stan cywilny $(p<0,001)$ i rodzina $(p<0,001)$ miały statystycznie istotny wpływ na stopień zadowolenia z życia. Akceptacja choroby była istotnie i dodatnio związana z satysfakcją z życia $(p<0,001)$, co oznacza, że im wyższa akceptacja choroby, tym większe zadowolenie z życia.

Wnioski: Związki między akceptacją choroby i zadowoleniem z życia powinny być dalej badane. 


\section{Introduction}

Cardiovascular diseases are defined as the modern epidemic of civilisation diseases and are one of the biggest health and social problems. The causes of cardiovascular diseases include modified and unmodified risk factors. The former largely depend on lifestyle and are usually abnormal diet, smoking, excessive alcohol consumption, diabetes, obesity, elevated cholesterol levels, stress, and lack of physical activity [1]. The most common cardiovascular disease is hypertension, which, if not properly diagnosed or treated, is one of the most important causes of coronary heart disease and heart failure [2].

Among cardiovascular diseases, the cause of the highest number of deaths is related to ischaemic disease, including myocardial infarction (ICD-10, I21), which in 2014 were responsible for $58 \%$ and $9 \%$, respectively, of cardiac deaths in Poland. The second group of causes of cardiovascular death are cerebral vascular diseases (ICD-10, I60-I69), accounting for $18 \%$ of deaths [3]. Unfortunately, the percentage of Poles dying from cardiovascular diseases will continue to increase, and forecasts indicate that in 2050 it may even reach $51 \%$ [4].

The emergence of the disease, especially in chronic form, almost always causes a crisis; therefore, adaptation to it requires the activation of a number of various defensive mechanisms. It seems that an essential role in this respect is played by the level of acceptance of the disease, recognition of the losses associated with it, dependence on other people, or self-esteem. Acceptance of the disease is usually the last stage of adapting to it. Then, the limitations connected with the occurrence of a given disease are recognised, which may also improve its course and influence further prognosis $[5,6]$. It is also important to assess the level of satisfaction with the patient's life in order to effectively and appropriately plan all therapeutic and rehabilitation activities. The concept of quality of life has thus gained a great deal of interest in health sciences in recent years, and patient descriptions of how they feel or function in relation to their health and well-being are increasingly linked to medical results.

Therefore, the aim of our research was to assess the degree of disease acceptance and overall life satisfaction of patients treated in cardiovascular wards and whether or not these features are related to each other.

\section{Aim of the research}

The aim of the study was to determine the influence of selected factors on the degree of disease acceptance and the level of life satisfaction in patients treated in cardiac wards, as well as to assess whether the level of disease acceptance affects the feeling of life satisfaction and vice versa.

\section{Material and methods}

The study involved 104 patients treated in the Świętokrzyskie Cardiology Centre in Kielce between July and October 2019. The study was approved by the Bioethics Committee and the head of the hospital. Each patient agreed to participate in the study. Moreover, the patients were informed that they are anonymous, and that the data obtained will be generalised and will be used only for scientific work. In total 112 questionnaires were distributed. Most of the treated patients filled in the questionnaire on their own, but some of them needed help in answering. Eight questionnaires were rejected due to incomplete filling in. Two people refused to participate in the study.

The data collection was based on an original questionnaire, which included single-choice questions about sociometric data such as gender, age, education, marital status, place and manner of residence, length of treatment, concomitant diseases, and number of hospitalisations.

The degree of disease acceptance in the studied group was determined using the Acceptance of Illness Scale (AIS) by B.J. Felton, T.A. Revenson, and G.A. Hinrichsen [6] in the Polish adaptation of Z. Juczyński [7]. The questionnaire contains eight statements describing the consequences of ill health, which boil down to accepting the limitations imposed by the disease, lack of self-sufficiency, sense of dependency, and lowered self-esteem. The higher the acceptance of the disease, the better the adaptation to it and the less mental discomfort. Responses are grouped according to a point value (1-5) where 1 means "I definitely agree" and 5 means "I definitely do not agree". The sum of all points is a general measure of the degree of acceptance of the disease and its scope ranges from 8 to 40 points. AIS has good psychometric properties for which the $\alpha$ Cronbach is 0.82 and the stability index is 0.69 .

The Satisfaction with Life Scale (SWLS) by Ed. Diener \& Lab., R.A. Emmons, R.J. Larsen, and S. Griffin [8] in the Polish adaptation of Z. Juczyński [7] was used. The questionnaire contains five statements to which the respondent responded on a seven-degree scale: 1 - I completely disagree, 2 - I disagree, 3 - I rather disagree, 4 - I neither agree nor disagree, 5 - I rather agree, 6 - I agree, 7 - I completely agree. For the original version, the reliability index ( $\alpha$ Cronbach) was 0.87 .

\section{Statistical analysis}

Statistical analysis were carried out using the R programme, version 3.6.1 [9]. The analysis assumed a significance level of 0.05 . Therefore, all $p$-values below 0.05 were interpreted as indicating significant dependencies. 


\section{Results}

The study involved 104 patients, including 64 men and 44 women, aged 24 to 90 years. The mean age \pm SD was $68.42 \pm 11.75$ years. The majority of respondents in the study group were married and/or in an informal partnership ( $n=76 ; 73.08 \%$ ). The most numerous group included patients aged 61-70 years $(n=38 ; 36.54 \%)$. A high percentage of respondents earned their living from retirement and/or disability benefits $(n=80 ; 76.92 \%)$. Most of the treated patients were people with secondary education $(71.15 \%)$ and inhabitants of big cities of up to 50,000 inhabitants. Only 34 (32.69\%) people lived in rural areas. The average length of treatment was $9.39 \pm 8.35$ years and ranged from 3 days to 50 years. The most numerous group comprised patients who had been treated from 0 to 10 years $(n=70 ; 67.31 \%)$. Among them, 29 had been ill from 11 to 20 years (27.88\%), four persons indicated that they had been ill from 21 to 30 years (3.85\%), and on person from 41 to 50 years.

Patients were hospitalised during the completion of the questionnaires due to various cardiac diseases, including heart failure, heart attack, ischaemic heart disease, atrial fibrillation and flutter, arteriosclerosis, angina pectoris, atrioventricular block, heart cancer, pulmonary embolism, or premature depolarisation. These diseases are categorised into four categories. The first group included patients with ischaemic heart disease and other forms of atherosclerosis, i.e. ischaemic heart disease, heart attack, arteriosclerosis, and angina pectoris (I.25.1; I.25.8; I.25.9; I.21.1; I.21.4; I.21.9; I.25.0; I.25.1; I.70.2; I.20.9). The second category was defined as arrhythmias in which patients with atrioventricular block, sinus syndrome, premature atrial depolarisation, paroxysmal tachycardia, atrial fibrillation, and flutter were qualified (I.44.1; I.44.2; I.49.5; I.49.1; I.47.9; I.4.48). The third category of patients with heart failure and valvular defects included patients with heart failure and main artery insufficiency (I.50.0; I.35.1). The last category included other acute conditions with atrial septal defect, cardiogenic shock, pulmonary embolism, and acute endocarditis (Q.21.1; R.57.0; I.26.0; I.33.9). The most numerous group comprised patients with heart failure $(n=32$; $30.77 \%)$, myocardial infarction $(n=23 ; 22.12 \%)$, and ischaemic heart disease $(n=10 ; 9.62 \%)$. The diseases associated with the main diagnosis in the treated patients included diabetes mellitus $(22.12 \%)$, cancer (4.81\%), depression $(2.88 \%)$, stroke $(2.88 \%)$, epilepsy $(3.85 \%)$, and chronic obstructive pulmonary disease (1.92\%). The clinical characteristics of the examined group of patients are presented in Table 1.
Table 1. Clinical characteristics of the examined group (main diagnosis, categories of disease groups, and comorbidities)

\begin{tabular}{|c|c|c|}
\hline Parameter & $N$ & $\%$ \\
\hline \multicolumn{3}{|l|}{ The main diagnosis: } \\
\hline Heart failure & 32 & 30.77 \\
\hline Myocardial infarction & 23 & 22.12 \\
\hline Ischaemic heart disease & 10 & 9.62 \\
\hline Atrial fibrillation & 7 & 6.73 \\
\hline Arteriosclerosis & 7 & 6.73 \\
\hline Angina pectoris & 7 & 6.73 \\
\hline Sinus syndrome & 5 & 4.81 \\
\hline Pulmonary embolism & 4 & 3.85 \\
\hline Atrioventricular block & 3 & 2.88 \\
\hline Atrial septal defect & 1 & 0.96 \\
\hline Cardiogenic shock & 1 & 0.96 \\
\hline Main artery insufficiency & 1 & 0.96 \\
\hline Primary tumour of the heart & 1 & 0.96 \\
\hline Paroxysmal tachycardia & 1 & 0.96 \\
\hline Premature atrial depolarisation & 1 & 0.96 \\
\hline \multicolumn{3}{|c|}{ The main diagnosis - categories of disease groups: } \\
\hline $\begin{array}{l}\text { Ischaemic heart disease and other } \\
\text { forms of atherosclerosis }\end{array}$ & 47 & 45.19 \\
\hline Heart failure and valvular defects & 33 & 31.73 \\
\hline Arrhythmias & 17 & 16.35 \\
\hline Other acute conditions & 7 & 6.73 \\
\hline \multicolumn{3}{|l|}{ Comorbidities: } \\
\hline Diabetes mellitus & 23 & 22.12 \\
\hline Cancer & 5 & 4.81 \\
\hline Epilepsy & 4 & 3.85 \\
\hline Depression & 3 & 2.88 \\
\hline Hypothyroidism, Hashimoto's thyroiditis & 3 & 2.88 \\
\hline Stroke & 3 & 2.88 \\
\hline Chronic obstructive pulmonary disease & 2 & 1.92 \\
\hline Buerger's disease & 1 & 0.96 \\
\hline Parkinson's disease & 1 & 0.96 \\
\hline
\end{tabular}

Almost half of the treated patients ( $n=44 ; 42.31 \%)$ were hospitalised $0-2$ times a year, and 40 patients (38.46\%) 3-4 times. The average number of hospitalisations was $3.08 \pm 1.86$ and ranged from 1 to 10 .

Table 2. Acceptance of cardiac disease. Descriptive statistics for the results of the AIS scale

\begin{tabular}{|lccccccccc|}
\hline Points & $\boldsymbol{N}$ & Mean & SD & Mean of question & Median & Min. & Max. & Q1 & Q3 \\
$8-40$ & 104 & 22.88 & 7.77 & 2.86 & 23 & 10 & 38 & 16.75 & 29 \\
\hline
\end{tabular}


Table 3. Acceptance of cardiac disease

\begin{tabular}{|lcc|}
\hline Negative health consequences (AIS) & Mean & SD \\
I have got problems to adjust to the limitations imposed by the disease (1-5) & 1.97 & 1.04 \\
Because of my health condition, I am not able to do what I like the most (1-5) & 2.06 & 1.05 \\
Sometimes illness makes me feel not needed (1-5) & 2.76 & 1.19 \\
Health problems make me more dependent on others than I want (1-5) & 2.72 & 1.29 \\
Illness makes me a burden to my family and friends (1-5) & 3.37 & 1.25 \\
My health makes me feel defective (1-5) & 2.94 & 1.21 \\
I will never be self-sufficient enough to the level I would like to be (1-5) & 2.71 & 1.3 \\
I think people that spend time with me very often feel embarrassed because of my illness (1-5) & 4.36 & 0.8 \\
\hline
\end{tabular}

Table 4. The results of tests of significance of the influence of independent factors on the degree of acceptance of the disease according to AIS obtained using the Spearman correlation coefficient

\begin{tabular}{|lcc|}
\hline $\begin{array}{l}\text { Examined } \\
\text { features }\end{array}$ & $\begin{array}{c}\text { Spearman } \\
\text { correlation coefficient }\end{array}$ & $P$-value \\
Age and AIS & -0.35 & $<0.001$ \\
$\begin{array}{l}\text { Number of the } \\
\text { hospitalisations } \\
\text { and AIS }\end{array}$ & -0.202 & 0.04 \\
\hline
\end{tabular}

Most people $(n=50 ; 48.08 \%$ ) were hospitalised for 6-10 days, 40 (38.46\%) people for 5 days, and 1 person for 45 days. The average length of hospitalisation was $7.25 \pm 4.78$ days and ranged from 2 to 43 days.

In order to recognise the negative consequences of ill health in patients treated in cardiac wards, the acceptance of illness scale (AIS) was applied. The questionnaire contained eight statements to which the respondent referred on a scale of 1-5. The higher the degree of disease acceptance, the better the adaptation and the lower the feeling of mental discomfort. For the examined persons, the assessments were summed up and the overall result calculated, which indicates the degree of acceptance of the disease.

In the studied group the scope of results ranged from 8 to 40 points. The mean value of the general disease acceptance index for all 104 patients was 22.88 \pm 2.86 . The highest score was 38 points and the lowest was 10 points. Therefore, the respondents neither accepted nor unaccepted their disease - they had a neutral attitude towards it. The results obtained in AIS are presented in Table 2 as mean values (M) and standard deviations (SD).

The study shows that patients, because of their condition, have difficulty adapting to the limitations imposed by the disease $(1.97 \pm 1.04)$, are unable to do what they like the most $(2.06 \pm 1.05)$, and will never be self-sufficient to the extent that they would like to be $(2.71 \pm 1.3)$. This means that in these areas the degree of acceptance of the disease was low. The statement "I think that people staying with me are often embarrassed because of my illness" had the highest

Table 5. Test results of significance of the influence of independent factors on the degree of acceptance of the disease according to AIS

\begin{tabular}{|c|c|c|c|c|}
\hline AIS [points] & Unmarried $(n=10)-\mathrm{A}$ & Married $(n=76)-B$ & Widowed $(n=18)-C$ & $P$-value \\
\hline Mean \pm SD & $21.9 \pm 8.52$ & $24.32 \pm 7.47$ & $17.39 \pm 6.27$ & 0.002 \\
\hline Median & 23.5 & 24.0 & 16.0 & \\
\hline Quartiles & $13.5-28$ & $18-30.25$ & $13-19.75$ & $B>C$ \\
\hline AIS [points] & Employed $(n=24)$ & \multicolumn{2}{|c|}{ Retirement/pension $(n=80)$} & $P$-value \\
\hline Mean \pm SD & $25.75 \pm 5.78$ & \multicolumn{2}{|c|}{$22.02 \pm 8.1$} & 0.021 \\
\hline Median & 26 & \multicolumn{2}{|c|}{20} & \\
\hline Quartiles & $23-29.25$ & \multicolumn{2}{|c|}{$15-28$} & \\
\hline AIS [points] & Living with family $(n=79)$ & \multicolumn{2}{|c|}{ Living alone or in a nursing home $(n=25)$} & $P$-value \\
\hline Mean \pm SD & $24.2 \pm 7.47$ & \multicolumn{2}{|c|}{$18.72 \pm 7.32$} & 0.001 \\
\hline Median & 24 & \multicolumn{2}{|c|}{16} & \\
\hline Quartiles & $18-30$ & \multicolumn{2}{|c|}{$13-20$} & \\
\hline
\end{tabular}


mean value $(4.36 \pm 0.8)$, which means that in this area both the sick and the closest persons/family better accepted the effects of the disease. The above values are presented in Table 3.

Based on the Mann-Whitney $U$ test analysis, it was found that variables such as age, marital status, employment, and number of hospitalisations had a statistically significant impact on the degree of acceptance of the disease in patients treated in cardiac wards. Acceptance of the disease was higher in the group of married patients (higher AIS score) and family members $(p=0.001)$ than in the group of widowed respondents $(p=0.002)$. Similarly, the acceptance of the disease was higher in the group of employed persons ( $p=0.021)$. Spearman's rank correlation analysis showed a statistically significant correlation between age and disease acceptance $(p<0.001)$, which means that the more advanced the age, the lower the AIS score (lower disease acceptance) and the number of hospitalisations $(p=0.04)$. The greater the number of hospitalisations, the lower the AIS score $(p=0.04)$. The above data are presented in Tables 4 and 5.

Variables such as gender, education, residence, main diagnosis, coexisting diseases, length of treatment, and length of hospitalisation did not determine the degree of disease acceptance $(p>0.05)$.

The SWLS questionnaire allowed the assessment of the sense of satisfaction with life in the studied group of patients. Satisfaction with life means satisfaction with one's own achievements and living conditions, while its evaluation is the result of comparing one's own situation with the norms set by the patient. The questionnaire used in the study contained five statements, with responses on a scale of 1-7. The higher the score, the greater the sense of compliance with the statement. The result of the questionnaire was converted into sten scores according to the standards given in the key to this tool. The results in scores 1-4 mean low, the results in scores 5-6 mean average, and the results in scores 7-10 mean high satisfaction with life. Of 104 patients treated, 53 (50.96\%) had an average sense of life satisfaction, $26(25.00 \%)$ had a low sense of life satisfaction, and 25 (24.04\%) had a high sense of life satisfaction. The above values are presented in Table 6.

In the case of the "I have achieved the most important things I wanted in my life" statement, the highest mean score of $4.62 \pm 0.97$ was obtained, which suggests that patients in the study group gave rather positive answers to this statement, i.e. "I rather agree" and/or "I agree". A high average was also obtained in the statement "I am satisfied with my life" $(4.36 \pm 1.06)$. The worst score was "If I could live my life again, I wouldn't want to change anything” with a score of $3.48 \pm 1.05$ and "My living conditions are excellent" with an average of only $3.81 \pm 1.01$, which means that most people indicated that they rather dis-
Table 6. Satisfaction with life

\begin{tabular}{|lccc|}
\hline SWLS [points] & Interpretation & $\mathbf{N}$ & $\%$ \\
$5-17$ & $\begin{array}{c}\text { Low satisfaction } \\
\text { with life }\end{array}$ & 26 & 25.00 \\
$18-23$ & $\begin{array}{c}\text { Average satisfaction } \\
\text { with life }\end{array}$ & 53 & 50.96 \\
$24-35$ & $\begin{array}{c}\text { High satisfaction } \\
\text { with life }\end{array}$ & 25 & 24.04 \\
\hline
\end{tabular}

Table 7. Satisfaction with life. Item analysis

\begin{tabular}{|lcc|}
\hline Item of SWLS & Mean & SD \\
In most ways my life is close to my ideal (1-7) & 3.86 & 1.04 \\
The conditions of my life are excellent (1-7) & 3.81 & 1.01 \\
I am satisfied with my life (1-7) & 4.36 & 1.06 \\
$\begin{array}{l}\text { So far, I have got the important things I want } \\
\text { in my life (1-7) }\end{array}$ & 4.62 & 0.97 \\
$\begin{array}{l}\text { If I could live my life over, I would change } \\
\text { almost nothing (1-7) }\end{array}$ & 3.48 & 1.05 \\
\hline
\end{tabular}

agree with the above statements. These data are presented in detail in Table 7.

In the next part of the paper we analysed the influence of independent variables, such as: gender, age, way of living, education, place of residence, duration of disease, co-morbidities, and frequency of hospital treatment on the average level of life satisfaction index according to SWLS. The values of quantitative variables in two groups were compared using the Mann-Whitney $U$ test. Comparison of three or more groups was performed by Kruskal-Wallis test, and in the case of statistically significant differences, posthoc analysis by Dunn test was performed in order to identify statistically significantly different groups. Correlations between quantitative variables were analysed using Spearman's correlation coefficient.

It was shown that marital status has a significant influence on the level of satisfaction with life of the treated patients. Married patients had a higher SWLS score, i.e. higher satisfaction with life than other groups $(21.28 \pm 3.86)$. This result was also higher in the group of patients living with family (21.09 \pm 4$)$. Life satisfaction was not affected by gender, age, education, employment, housing, number of hospitalisations, main diagnosis, coexisting diseases, length of treatment, and length of hospitalisation $(p>0.05)$.

In order to get to know the whole of the abovementioned issue, the analysis of the examined sample was performed not only from the level of two characteristics, i.e. AIS and SWLS, but it was also ascertained whether they were related to each other. Pearson's correlation coefficient was used for this analysis. The 


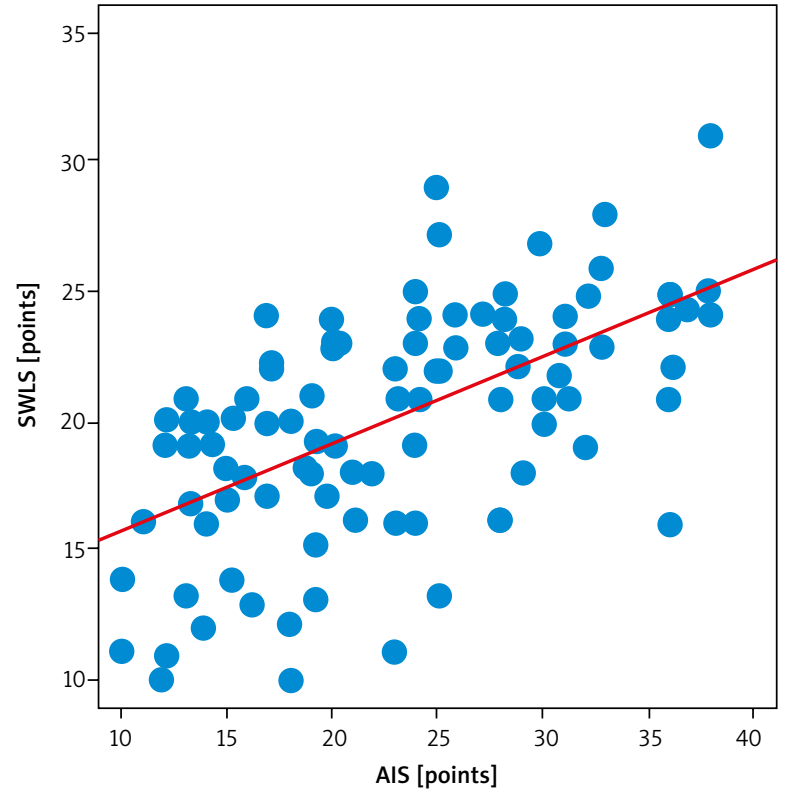

\begin{tabular}{|ccc|}
\hline $\begin{array}{c}\text { Examined } \\
\text { features }\end{array}$ & $\begin{array}{c}\text { Spearman } \\
\text { correlation coefficient }\end{array}$ & $P$-value \\
\hline AIS and SWLS & 0.636 & $<0.001$ \\
\hline
\end{tabular}

Figure 1. Correlation between SWLS and AIS

study showed a significant and positive correlation, which means that the higher the AIS score - i.e. greater acceptance of the disease - the higher the SWLS score, i.e. greater satisfaction with life $(p<0.001)$. This result also works the other way around, i.e. the higher the satisfaction with life, the higher the acceptance of the disease. The above relationships are presented in Figure 1.

\section{Discussion}

The data obtained prove that the acceptance of the disease influences its course and prognosis. However, the disease - especially if chronic - is often difficult to accept because it usually limits the daily life of the patient and his/her family. The patient is not always able to perform all activities, and in many cases he/she becomes dependent on others. Therefore, the literature emphasises the positive influence of the acceptance of the disease and its limitations on the improvement of mental and physical comfort. This is important because people with lower acceptance of the disease declared less strength and motivation to act, disturbed sleep, and felt stronger pain, as well as social isolation and limited mobility [10]. The fact that the acceptance of the disease may have a positive impact on the compliance with therapeutic recommendations, the level of cooperation with medical personnel [11] and the general sense of satisfaction with life is also important.
In the study group, the level of disease acceptance was 22.8 points, which corresponds to the average level of disease acceptance and/or neutral attitude towards the disease. A similar result was obtained in the group of patients with unstable angina pectoris (21.52 points) [5], with atrial fibrillation and flutter (22.67 points) [11, 12], with heart failure [13] with ischaemic heart disease (23.50) [14], after myocardial infarction (22.14) [after: 5], or among patients treated in invasive cardiology wards [15]. Slightly different results were obtained in the study by Mucha et al. [16] among 92 patients hospitalised for myocardial infarction. In the studied group, the mean index was at the level of 28.08, which indicates a high degree of acceptance of the disease.

The available literature emphasises that many factors influence the acceptance of the disease. The studies showed that the level of disease acceptance was age dependent. In the study of Łuczyk et al. [5], in patients with angina pectoris it was noted that in the age group up to 50 years the degree of disease acceptance was higher in comparison with those aged 51-60 years, 61-70 years, and over 70 years, where the disease acceptance was at the lowest level. A similar result was obtained in the study by Kulig and Filanowicz in patients hospitalised for heart failure [13]. The lowest level of disease acceptance was found among respondents over 70 years of age. This is consistent with our research, which has shown that the older the age, the lower the acceptance of the disease.

It seems that the disease may have a significant impact on patients' lives due to its chronic nature. The research shows that patients treated for angina pectoris for up to three years accepted their disease significantly more than patients treated for 4-10 years, 11-20 years, or more than 20 years. The worst acceptance of the disease was in the group of patients with more than 20 years of illness [5]. Similarly, in the studies of Jankowska-Polańska et al. [17] in patients with hypertension, it was noted that the longer the treatment time, the lower the acceptance of the disease. However, taking into account the patients treated in this study, the length of treatment did not determine the degree of acceptance of the disease. Therefore, the data obtained in the literature are inconsistent and require further verification. However, this may mean that regardless of the duration of the disease, it is still a difficult experience and patients are constantly struggling with its negative consequences.

Studies have shown that marital status affects the level of acceptance of the disease. Married couples accepted their illness more than unmarried or widowed couples. Individuals living with their families also declared a higher degree of acceptance of the disease. This may be due to better coping with the consequences of the disease by helping a loved one to overcome the problems associated with the disease 
and to adapt to certain restrictions associated with it. The research carried out by other authors also shows that the married respondents accepted their disease significantly more than the unmarried respondents or widowed persons [5].

It seems that employment is another important factor influencing the degree of acceptance of the disease. It was noted that working people accepted the disease more than those who were retired. The lack of professional activity also translated into a lower level of acceptance of the disease in other works on the subject $[5,18]$. The reason for such dependence may be related to greater satisfaction with life related to the lack of resignation from fulfilling the existing roles, developing their competences, fulfilling themselves at work, or simply the feeling of being needed.

Statistical analysis also revealed significant differences in AIS evaluation between patients who were hospitalised one to two times a year and those who were hospitalised five to eight times or more often. As it was shown, the greater the number of hospitalisations, the lower the acceptance of the disease. A similar trend was observed in the work of other authors [5].

Coexisting diseases are another factor that may affect the level of disease acceptance. In the authors' studies, the most common coexisting disease in cardiologically treated patients was diabetes (22.12\%), which was also declared as the most common by $31 \%$ of patients with hypertension in the work of Pokorna-Kałwak et al. [19]. In this analysis, however, no correlation was observed between diabetes, other coexisting diseases, and the level of disease acceptance. The presence of coexisting diseases had no significant influence on the scale of disease acceptance also in the study of Uchmanowicz [18]. However, in the Jankowska-Polańska study [17] it was noted that among patients with hypertension, an independent factor negatively influencing the level of disease acceptance was coexistence of ischaemic heart disease, atherosclerosis, and vascular disease.

Interestingly, gender did not determine the level of disease acceptance in the study. It is consistent with the results of Muszalik and Kędziora-Kornatowska [20], Jankowska-Polańska et al. [17] and Kulig and Filanowicz [13], in which no such correlation was observed. It seems that people with higher education are more aware of the risks associated with noncompliance with the recommendations, so they are more willing to learn how to cope with the disease, obtain new information about it, and better adapt to the disease. Such data were obtained by Łuczyk et al. [5] and Szyguła-Jurkiewicz et al. [21] when evaluating patients treated for cardiovascular diseases. Patients with higher education accepted the disease more than those with secondary, vocational, or primary education. However, in this study no such dependence was obtained, which means that education was not a fac- tor determining the degree of acceptance of the disease in the study group. The lack of such a relationship is also confirmed by the report by Kurowska and Ratajczyk [22] among patients with diagnosed hypertension. Data on this subject are therefore inconsistent and require further verification.

The place of residence is another factor taken into account. It seems that living in the city creates more opportunities and significantly facilitates access to health services, support groups, and educational and preventive programmes. However, this assumption was not confirmed in this study, which means that among patients treated in cardiac wards it did not determine the degree of acceptance of the disease. However, this highlights the importance and need for education in this area and the importance of interdisciplinary cooperation.

Disease can also affect the sense of overall satisfaction with life. However, the results of our own research concerning the sense of satisfaction with life of patients treated in cardiac wards were varied. As much as $50.96 \%(n=53)$ of patients declared a medium score of life satisfaction, the remaining $25 \%$ $(n=26)$ indicated a low level, and 24\% $(n=25)$ a high level. Similar results were obtained by Glińska et al. [23], Kupcewicz and Abramowicz [24], and Kulig and Filanowicz [13]. Slightly different data in this respect were obtained by Reczek et al. [25] in patients with an implanted cardioverter-defibrillator. In the whole group, every third patient (34.5\%) had a high sense of satisfaction, and a slightly higher percentage (39.6\%) had an average sense of life satisfaction. On the other hand, only one in 4 (25.9\%) respondents presented a low sense of satisfaction with life.

Various factors may also influence the level of life satisfaction, gender being one of them. In our own research, however, no statistical significance was found between the level of satisfaction with life and gender. Similar data were obtained by Ogińska-Bulik [26] in patients after myocardial infarction or Kulig and Filanowicz [13] in patients with heart failure.

Age, education, employment, place of residence, length of illness, or number of hospitalisations are the next factors. However, in the studies conducted, none of these factors affected the sense of satisfaction with life. On the contrary, data obtained in the works of other authors showed that education and place of residence were variables that had a significant impact on the level of satisfaction with life [24]. Other data were found in the study by Reczek et al. [25], in which it was noted that people who retired because of disability had lower satisfaction with life than those who were professionally active and retired because of age. The data in this respect are therefore not homogeneous and need further verification.

It is worth noting that in our study we found a highly statistically significant correlation between 
the level of satisfaction with life in the examined group and marital status and the way of living of the treated patients. In the group of married and family members, the SWLS score was higher (satisfaction with life) than in the other groups. These results are consistent with the data obtained by Reczek et al. [25], who determined the level of life satisfaction of patients with an implanted cardioverter-defibrillator. Also, Glińska et al. [23] noted a positive correlation between social support and life satisfaction in the group of patients with ischaemic heart disease.

Because the problem of disease acceptance is a common issue in the literature, especially in the group of chronically ill patients, it was decided to look at this phenomenon from a broader perspective, taking into account not only patients treated in cardiac wards [26]. A significantly lower level of disease acceptance in comparison to our patients was shown in the study by Marzec et al. [27] when assessing the level of disease acceptance in patients with chronic renal disease, haemodialysed, and diabetic, Kupcewicz and Abramowicz [24] in patients treated for chronic obstructive pulmonary disease, as well as Niedzielski et al. [14] investigating the level of disease acceptance in chronic diseases such as diabetes, chronic kidney disease, bronchial asthma, and ischaemic heart disease. Moreover, in their studies, they emphasise the statistically significant dependence of the disease acceptance level on gender (a higher acceptance level is presented by men), age (a higher acceptance level is presented by people under 55 years of age), and place of residence (a higher acceptance level is recorded in people living in a city). Although these results are consistent with our age-related research, they differ in terms of gender and place of residence. However, values similar to those obtained in this study were found in patients with colorectal cancer treated with chemotherapy [28]. A higher level of acceptance was achieved in patients with type 1 diabetes [29], bronchial asthma [30], or psoriasis [31] or in patients hospitalised for lung cancer [32].

According to the literature, the acceptance of the disease also has a positive effect on compliance with medical recommendations, and its absence is associated with a lower level of compliance and adherence [11]. This is also confirmed by the studies of Kurowska and Ratajczyk [22] conducted among 77 patients with type 2 diabetes, which showed that the better the patient knows and accepts his or her disease, the more motivated he or she is to solve difficult situations related to it and the more willing they are to take an active part in the treatment process. On the basis of these data it can be concluded that the acceptance of the disease plays an important role in all chronic diseases. Moreover, when the quality of life of the affected person deteriorates it may translate into overall satisfaction with life of the affected person's closest relatives. Thus, the higher the acceptance of the disease, the greater the satisfaction with life - and vice versa. Interestingly, the same conclusion was drawn in the study by Kaźmierczak et al. [33] in women treated for reproductive organ diseases.

A fundamental role in reducing the health, psychological, and social consequences of heart diseases is played by broadly understood complex preventive measures, which may significantly improve the degree of acceptance of the disease, and thus the satisfaction with life of the patients treated in cardiac wards. It also seems important to involve psychologists in the work of the ward. Cooperation between a psychologist and medical staff would help to strengthen the mental resilience of the treated patients, calm the intensity of negative reactions related to the disease and hospitalisation, and, through education, reduce stress and educate people how to deal constructively with difficult situations. Psychological assistance aims to make the patient aware and convince him/her of the possibility of influencing his/her own health and modifying the existing health behaviours and lifestyles, at the same time increasing the sense of acceptance of the disease and related limitations, thus improving the overall quality and satisfaction with life.

Limitations of the current study primarily include the moderate size and rather heterogeneous character of the study group patients with various main cardiac diagnoses and with different comorbidities. The strength of this work is the use of two short standardised questionnaires, which significantly shortened the time for completion.

Despite the limitations, the study showed a significant relationship between the level of acceptance of disease and the level of life satisfaction, which may bring beneficial information for the improvement of health care procedures and implementation of preventive programs.

\section{Conclusions}

There is a statistically relevant correlation between the level of disease acceptance and satisfaction with life among the patients hospitalised due to cardiovascular diseases in cardiology departments. Consequently, less acceptance of the disease means less satisfaction with life. Patients have a neutral attitude towards the disease. Acceptance of illness is greater in the group of married people and those living with their families. More educated and professionally active people have greater acceptance of the illness as well. The level of disease acceptance declines with age. More hospitalisation means less acceptance of the disease. Patients declared a medium sense of life satisfaction. The level of satisfaction with the life of the patients being hospitalised is affected by marital status and/or living with the family. 


\section{Acknowledgments}

Project financed under the program of the Minister of Science and Higher Education called "Regional Initiative of Excellence”, project no. 024/RID/2018/19, amount of financing 11,999,000 zł.

\section{Conflict of interest}

The authors declare no conflict of interest.

\section{References}

1. Wróblewska I, Adamowicz E, Sochocka L, Steciwko A. Importance of angina pectoris prevention. Own study in interventional cardiology unit in Zgorzelec. Fam Med Prim Care Rev 2011; 13: 257-263.

2. Krzych ŁJ, Jaros A, Rybicki J, Bochenek A, Błońska-Fajrowska B. Efficacy of pharmacological treatment of hypertension in patients hospitalized in cardiac rehabilitation centre. Nadciśnienie Tętnicze 2010; 14: 261-266.

3. Wojtyniak B, Goryński P. Sytuacja zdrowotna ludności Polski i jej uwarunkowania. Narodowy Instytut Zdrowia Publicznego - Państwowy Zakład Higieny, Warszawa 2016.

4. Jankowski P. Recommendations for cardiovascular disease prevention in 2018. Kardiol Inwazyjna 2017; 12: 42-48.

5. Łuczyk R, Juśko A, Łuczyk M, Krzyżanowska E, Plottke A. Acceptance of the disease in patients with a diagnosis of unstable angina. J Educ Health Sport 2016; 6: 453-470.

6. Felton BJ, Revenson TA. Coping with chronic illness: a study of illness controllability and the influence of coping strategies on psychological adjustment. J Consulting Clin Psychology 1984; 52: 343-353.

7. Juczyński Z. Narzędzia pomiaru w promocji zdrowia. Pracownia testów Psychologicznych Polskiego Towarzystwa Psychologicznego, Warszawa 2001; 134-139, 168-172.

8. Diener ED, Emmons RA, Larsen RJ, Griffin S. The satisfaction with life scale. J Personality Assessment 1985; 49:, 1.

9. R Core Team (2019). R: A language and environment for statistical computing. R Foundation for Statistical Computing, Vienna, Austria. URL https://www.R-project.org/.

10. Obiegło M, Uchmanowicz I, Wleklik M. The effect of acceptance of illness on the quality of life in patients with chronic heart failure. Eur J Cardiovasc Nurs 2016; 15: 241-247.

11. Martynow A, Lefek K, Wierzbicka B, Chudiak A, Lomper K, Jankowska-Polańska B. Effect of acceptance of illness on treatment adherence in atrial fibrillation patients. J Educ Health Sport 2017; 7: 154-170.

12. Skorupska-Król A, Szewczyk I, Kurleto P. Quality of life and illness acceptance among patients suffering from persistent atrial fibrillation (AF). Państwo i Społeczeństwo 2019; 1: 27-41.

13. Kulig K, Filanowicz M. Correlation analysis between disease acceptance and satisfaction with life among patients hospitalized due to heart failure in cardiology departments. Pol J Appl Sci 2018; 4: 18-23.

14. Niedzielski A, Humeniuk E, Błaziak P, Fedoruk D. Stopień akceptacji choroby $\mathrm{w}$ wybranych chorobach przewlekłych. Wiad Lek 2007; 60: 224-227.

15. Kurpas D, Bąk E, Seń M, Wróblewska I, Mroczek B. Quality of life in patients of the interventional cardiology unit. Fam Med Prim Care Rev 2014; 16: 120-123.
16. Mucha A, Majda A, Nawalana A. Religiousness and acceptance of the disease in patients after myocardial infarction. Pieleg Pol 2019; 4: 345-353.

17. Jankowska-Polańska B, Ilko A, Wleklik M. Influence the acceptance of the disease on quality of life of patients with hypertension. Arterial Hypertension 2014; 18 : 143-150.

18. Uchmanowicz I. Acceptance of illness and quality of life in heart failure. Gerontol Pol 2015; 1: 3-10.

19. Pokorna-Kałwak D, Muszyńska A, Mastalerz-Migas A. Pacjent $\mathrm{z}$ nadciśnieniem tętniczym $\mathrm{w}$ wieku podeszłym - wpływ choroby i prowadzonego leczenia na samopoczucie chorego. Psychoger Pol 2008; 5: 37-46.

20. Muszalik M, Kędziora-Kornatowska K. Jakość życia przewlekle chorych pacjentów w starszym wieku. Gerontol Pol 2006; 14: 185-189.

21. Szyguła-Jurkiewicz B, Kowalska M, Mościński M. Jakość życia jako element oceny stanu zdrowia i efektywności leczenia chorych ze schorzeniami układu sercowo-naczyniowego. Folia Cardiol Excerpta 2011; 6: 62-71.

22. Kurowska K, Ratajczyk M. Wpływ zachowań zdrowotnych na jakość życia osób z rozpoznaniem nadciśnienia tętniczego. Nadciśnienie Tętnicze 2012; 16: 345-352.

23. Glińska J, Cezak E, Lewandowska M, Brosowska B. Social support compared with life satisfaction of patients with ischemic heart disease. Probl Pieleg 2014; 22: 265-270.

24. Kupcewicz E, Abramowicz A. Influence of selected sociodemographic factors on degree of illness acceptance and on level of satisfaction with life in patients with chronic obstructive pulmonary disease. Hygeia Public Health 2015; 50: 142-148

25. Reczek A, Wojdyła-Piekarz J, Kawalec-Kajstura E. Life satisfaction in patients with implantable cardioverter defibrillator. Hygeia Public Health 2018; 53: 356-362.

26. Ogińska-Bulik N. Posttraumatic growth and satisfaction with life in persons after myocardial infarction. PFP 2014; 19: $140-154$

27. Marzec A, Andruszkiewicz A, Banaszkiewicz M. Poczucie koherencji, akceptacja choroby a funkcjonowanie w chorobie przewlekłej chorych na chorobę nerek, chorych na cukrzycę, hemodializowanych - doniesienia wstępne. Piel XXI Wieku 2011; 2: 51-56.

28. Kapela I, Bąk E, Krzemińska SA, Foltyn A. Evaluation of the level of acceptance of the disease and of satisfaction with life in patients with colorectal cancer treated with chemotherapy. Piel Zdr Publ 2017; 26: 53-61.

29. Basińska MA. Funkcjonowanie psychiczne pacjentów w wybranych chorobach endokrynologicznych. Uwarunkowania somatyczne i osobowościowe. Wydawnictwo Uniwersytetu Kazimierza Wielkiego, Bydgoszcz 2009.

30. Rusin-Pawełek E, Uchmanowicz I, Jankowska-Polańska B, Panaszek B, Fal MA. Akceptacja choroby pacjentów chorych na astmę oskrzelową a kontrola astmy oskrzelowej. Współcz Alergol 2012; 7: 61-68.

31. Basińska MA, Kasprzak A. The relationship between strategies of coping with stress and acceptance of illness among patients with psoriasis. Przegl Dermatol 2012; 99: 692-700.

32. Chabowski M, Polański J, Jankowska-Polanska B, Lomper K, Janczak D, Rosinczuk J. The acceptance of illness, the intensity of pain and the quality of life in patients with lung cancer. J Thorac Dis 2017; 9: 2952-2958. 
33. Kaźmierczak M, Gebuza G, Izdebska EK, Mieczkowska E, Gierszewska M. Influence of selected sociodemographic, obstetric and psychological factors on thelevel ofacceptance of illness in women treated for reproductive system diseases. Piel Zdr Publ 2018; 8: 110-122.

\section{Address for correspondence:}

\section{Katarzyna I. Białek}

Institute of Medical Sciences

Faculty of Medicine and Health Sciences

Collegium Medicum

Jan Kochanowski University

al. IX Wieków Kielc 19 A, 25-317 Kielce, Poland

Phone: +48 512318732

E-mail: katarzynabialek@vp.pl 